\title{
Customary Practices of Sharing Inheritance: An Analysis of Society Practices in Pidie Aceh Darussalam
}

\author{
Zaitun Muzana \\ (The Faculty of Islamic studies, Universiti Sains Malaysia Pulau Pinang 1800 \\ Gelugor, Pulau Pinang, Malaysia, E-mail: titel80@yahoo.com) \\ Jasni Bin Sulong \\ (The Faculty of Islamic studies, Universiti Sains Malaysia Pulau Pinang 1800 \\ Gelugor, Pulau Pinang, Malaysia, E-mail: jasni@usm.my) \\ Faisal Bin Husen Ismail \\ (The Faculty of Islamic studies, Universiti Sains Malaysia Pulau Pinang 1800 \\ Gelugor, Pulau Pinang, Malaysia, E-mail: titelfaisal80@gmail.com)
}

\begin{abstract}
Abstrak:
Pengurusan berkaitan harta peninggalan si mati adalah merupakan salah satu perkara penting yang mesti dilakukan oleh waris yang masih hidup. Namun amalan ini berbeda-beda dalam setiap masyarakat terutama di kawasan yang dipengaruhi oleh amalan adat. Harta peninggalan si mati bukan hanya digunakan untuk pengurusan jenazah dan pembagian kepada para waris, bahkan ia juga digunakan untuk tujuan fidyah akibat tidak melakukan sholat dan lain-lain lagi yang ditetapkan dalam masyarakat adat. Persoalan adat ini penting untuk dikaji dan diperjelas kepada masyarakat, karena ia bukan saja tiada dalam syara' bahkan menyebabkan hak orang lain semakin berkurang. Maka kajian ini dilakukan untuk menyelidiki sejauhmana amalan adat mempengaruhi kaedah pembagian harta pusaka dalam masyarakat Pidie di Nanggroe Aceh Darussalam Indonesia.
\end{abstract}

\section{Kata Kunci:}

Amalan Adat, Harta Pusaka Islam, Pidie, Pembagian Harta Pusaka

\begin{abstract}
:
Handling inheritance from a deceased person is one of important matters that must be performed by the surviving heirs. However, the practice varies in communities, especially in areas affected by customary practices. The wealth of inheritance from the deceased is not only used as payment of funeral expenses and to be distributed to the heirs, but also used for the purpose of fidyah (compensation) for prayers left and others set in indigenous communities. The issue of
\end{abstract}

al-1hkâm Vol.11 No.2 Desember 2016

DOI 10.19105/al-ihkam.v11i2.1037 
tradition is important to study and clarify to society because it is not recognized in Islamic teachings and can even lead to diminishing the rights of others. Thus, this study aims to examine the extent of customary practices would affect the principle of inheritance distribution in the society of Pidie, Aceh, Indonesia.

\section{Key Words:}

Customary Practices, Islamic inheritance, Pidie, Wealth of Inheritance Distribution

\section{Introduction}

It is believed that Aceh is one of the region's earliest spread of Islam in Southeast Asia. Aceh has implemented Islamic law in government affairs after the ruling king followed by the Acehnese accepted Islam as the official religion. Every effort has also been made to perpetuate Islamic law in daily life of Acehnese. For this to happen, Islamic law has been made as the government law in Aceh, including laws regarding inheritance.

The term custom means an act done repeatedly so that it becomes a character. ${ }^{1}$ According to Musthafa Ahmad al-Zarqa, ${ }^{2}$ custom encompasses habits done by individual or community, both good and bad habits. ${ }^{3}$ Thus, custom can be defined as an act and circumstances that happen repeatedly so that accepted by and become a character, either it is general or specific habit in nature.

At the beginning of the advent of Islam, Islam helped recognize the customary practices in inheritance division of Muslims so that, later, they are gradually abrogated. A principle that prioritizes the male heir solely is fixed by Islam to the division ratio of the two one between men and women. ${ }^{4}$ Likewise, the heredity principle of alMaqt where children may have shares of the inheritance of the father's widow by marrying her and keeping it together, has been abrogated

\footnotetext{
${ }^{1}$ Majma' al-Lughah al-'Arabiyyah, al-Mu jam al-Wasîth, Ed. IV, (Qahirah: Maktabah al-Syuruq al-Dawliyyah, 2004), 635.

2 Musthafa Ahmad al-Zarqa, al-Madkhal al-Fiqh al-Âm. Vol. 2, (Damsyiq: Dar alQalam, 2004), 871.

3 'Abd al-Karim Zayand, al-Wajîz fi Syarh al-Qawấid al-Fiqhiyyah fi al-Syarî'ah alIslâmiyyah, (Beirut: Muassasah al-Risalah, 2001), 101.

${ }^{4}$ Muhammad 'Ali al-Shabûnî, Safwah al-Tafâsir, Vol. 1, (Kaherah: Dar al-Sabuni, n.d.), 260.
} 
by Islam in Q.S al-Nisa (4):19. ${ }^{5}$ Meanwhile, the customary practice of inheritance through the pledge of allegiance or oath between two friends to inherit each other (half) is preserved for some time. Also, allocation of wealth of inheritance to an adopted child (al-tabanni) is initially justified for his service in protecting the family, ${ }^{6}$ and so are the results of brotherhood (muakhah) between Muhâjirin and Anshâr which allows them to be eligible for shares of legacy. Heredity through half and tabanni was still preserved at the beginning of Islam which is then abrogated with the revelation of Surah al-Ahzab verse 6 .

In sum, the advent of Islam has had great impacts and changes on the Arabs in particular and the world in general. Islam has been able to change the low level of way of thinking of jâhiliah Arab society (age of ignorance) to be able to achieve the civilized world with high level of way of thinking. The result of the changes can also be seen with regard to the division of wealth of inheritance.

In the third year of the Hijra, the changes of inheritance system applied when the division of wealth was limited only to heirs of offspring (nasab), marriage (mushâharah) and walâ'. This applies after the revelation of inheritance verse, that is Q.S al-Nisa (4): 11 where the wife and two daughters of Sa'ad Ibn al-Rabi' have no part of the Sa'ad's wealth of inheritance because his brother had taken all the treasures. Once reported to the Prophet then He ordered that a certain part should be handed over to the wife and daughters of Sa'ad.7

Based on the development described above, it is clear that custom got an important position at the early Islam in which it has been a part of legal reasoning. In a simple word, it is allowed to take custom as a reference if it meets certain conditions. For example the custom practiced is widely accepted in society and not in conflict with syara' (Islamic law). ${ }^{8}$ The aforementioned explanation shows that customs is one of the sources of law that is recognized and used in Islam when it meets requirements.

\footnotetext{
${ }^{5}$ Muhammad 'Ali al-Shabûnî, Ibid., 266.

6 Nasr Farid Muhammad Wasil, Fiqh al-Mawârith wa al-Washiyyah fi al-Syarî'ah alIslâmiyyah, (Mesir: al-Maktabah al-Taufiqiyyah), 1995, 14-15.

7 See Al-Turmudzi (n.d.), Sunan al-Turmudzi, Vol. III, (Beirut: Dar al-Kutub al'Ilmiyyah), 361.

8 'Abd al Karim al-Namlah (1999), al-Jami’ li Masa'il Usul al-Fiqh, (Riyadl: Maktabah alRusyd), 394-395.
} 


\section{Islamic Law of Inheritance (al-Farâid)}

The words farâid means bringing in predetermined portion. ${ }^{9}$ The term inheritance (farâid) is interpreted differently by Islamic jurists. According to scholars of Hanafiyyah and Hanâbilah, ${ }^{10}$ farâid is the science of ushûl (the rules and stipulation) of jurisprudence and hisâb (estimates) to determine the portion of wealth of inheritance received by each heir. ${ }^{11}$ Meanwhile, some scholars of Shafi iyyah state that farâid is masâil (problems) of division of wealth of inheritance in the way of either fard (predetermined portion) or $t a^{\prime} s i b$ (residuals that are not determined by Islamic law). ${ }^{12}$ In sum, al-farâid emphasizes how to calculate the wealth of inheritance to be distributed to heirs entitled to the shares of the wealth of the deceased.

The argument about inheritance is expressed in the Koran and Hadith both in the form of general (mujmal) and detailed (mufassal) verses. ${ }^{13}$ In terms of mujmal verse, it is said in Q.S al-Nisa ' (4): 7 that for men and women is a share from the parents and their relatives, be it a little or much. ${ }^{14}$ With regard to the mufassal verse, the division of the wealth of inheritance is described in detail in three verses that is, in verse 11, 12 and 176 of Surah al-Nisa '. 15

The hadith of the Prophet also discusses about the inheritance both in the way of dilâlah 'ammah (mujmal) such as prohibition to inherit wealth from those of different religion, 16 and dilâlah khâshshah (mufassal $)^{17}$ such as Hadith explaining the portion to be received by each beneficiary, like half for daughters, one-sixth for granddaughter

\footnotetext{
${ }^{9}$ Al-Ab Luwis Ma'lûf al-Yasu'i, al-Munjid fi al-Lughah. (Beirut: al-Kathulikiyyah, N.d), 577.

10 Ibrahim al-Faradi, al-'Adhb al-Faid Syarh 'Umdah al-Farid, Vol. 1, (Beirut: Dar alKutub al-'Ilmiyyah, 1999), 12.

11 Ibn 'Âbidin, Rad al-Mukhtar 'ala al-Dur al-Mukhtar Syarh Tanwîr al-Abshâr, Vol.10, (Riyadl: Dar 'Alim al-Kutub, 2003), 489.

12 Al-Bayjurî (1999), Hasyiyyah al-Bayjurî 'ala Syarh Ibn al-Qâsim 'ala Syarh Matn Abi Syujâ', Ed. 2, Vol.2, (Beirut: Dar al-Kutub al-Islamiyyah, 1999), 84.

13 Muhammad al-Syahat al-Jundi, al-Mirath fi al-Syarî'ah al-Islâmiyyah, (Kaherah: Dar al-Fikr al-'Arabi, N.d), 43

${ }^{14}$ Q.S al-Anfal (8): 75 and al-Ahzab (33): 6

${ }_{15}$ Musthafa'Asyur, 'Ilm al-Mirath, (Kaherah: Maktabah al-Qur'an, N.d), 35.

16 See Al-Turmudzi, Sunan al-Turmudzi..., Vol. 4, 369.

17 Muhammad al-Syahat al-Jundi, al-Mirath...,47.
} 
(from son) to fulfill two-thirds and the rest is for the sisters, 18 and a hadith about the right of grandmother to inheritance. 19

Before the wealth of inheritance is shared, the funeral expenses and debt must be paid off, and the will must be implemented. The three initial things are stated in Q.S al-Nisa' (4): 11-12 as much as four times that the division of the inheritance to the heir is done after the will has been fulfilled and the debt has been paid off. The jurists agree on this point based on clear passages of the aforementioned verses. ${ }^{20}$ With regard to the debt, the Prophet states that a Muslim is hung until the debt is paid off. And so a narration from 'Ali said that the Prophet prioritizes debt payments before the implementation of the will. ${ }^{21}$

\section{Pidie Court Division of Islamic Inheritance Distribution}

Pidie is an area of Nanggroe Aceh Darussalam. In Pidie society, the division of wealth of inheritance is managed by the two ruling parties, namely:

1) Village court, namely the division of inheritance is done by a person who is appointed as a leader in every village such as imam of a mosque, imuem meunasah, geuchik, and imuem mukim, teungku (religious leaders) to help and give their views on the procedure of the division of inheritance according to Islamic law. The procedure is applied in Pidie and recognized in the law of Aceh such as Regulation No. 7 Year 2000 concerning local custom in particular in Chapter V, Article 11, paragraph 1:

"Geuchik (village chief) has the power to resolve disputes / conflicts/ problems occurred in the Gampong (village), both problems within families, between families and social problems that arise in the community through a customary meeting of the Village." 22

18 See Al-Qazawayni (n.d.), Sunan Ibn Majah, Vol.2, (Beirut: al-Maktabah al-'Ilmiyyah, N.d) 909.

19 Al-Bayhaqi, al-Sunan al-Kubra, Vol.6 (Beirut: Dar: al-Ma'rifah, N.d), 235.

${ }^{20}$ Ibn Nujaym, Al-Bahr al-Râiq Syarh Kunz al-Daqâiq, Vol.2, (Kaherah: Dar al-Kitab alIslami, N.d), 191-192.

21 Al-Qazwayni, Sunan Ibn Majah, Vol.2, (Beirut: al-Maktabah al-`Ilmiyyah, N.d), 806, 906.

22 See also Act No. 5 /2003 on the Gampong Government, and article 9 Fatwa of MPU No. 2/ 2005 which state that Sharia Court have to give a chance to the geuchik and mukim to resolve disputes on orphans before referral to the Court. 
Delegation of authority to the village chief is done through a law enforcement to solve problems in the village, including reconciling conflicts, family disputes and wealth of inheritance division cases. Customary meeting is one of ways done to resolve those problems. Initially, the wealth of inheritance is divided according to the agreement of heirs, for example women have more shares than men. If some heirs do not agree with the decision, then the Village Court will refer to Islamic law. ${ }^{23}$ If still no agreement is achieved amongst the heirs, the case will be brought to the Regional Sharia Court.

2) Regional Sharia Court constitutes mediatory institution for division of wealth of inheritance in the region of Pidie under Sharia Court of Sigli. ${ }^{24}$ Based on the case record in the Sigli Sharia Court from 2007 to 2013, the Court has heard and decided no more than 10 cases regarding inheritance each year. ${ }^{25}$ It shows that many cases regarding inheritance has been decided in the village court level due to the high public confidence and satisfaction on the decision of geuchik and teungku. ${ }^{26}$ Among the cases thid study refers to here is such as legalization of heirs ${ }^{27}$ and the division of wealth of inheritance. ${ }^{28}$ All these cases have been decided based on the Islamic law contained in the Compilation of Islamic Law (ILC), Indonesia. This is in accordance with Article 53, Nanggroe Aceh Darussalam Province Qanun (regulation) No. 10 of 2002 which reads: "The law material to be used in resolving the case, as mentioned in Article 49 is derived from or in accordance with the Islamic Sharia which will be arranged in

\footnotetext{
${ }^{23}$ See regional regulation No. 7/2000 concerning the life of indigenous customs, particularly in chapter II article 3.

24 See Article 49 Act No. 7/1989 about Religious Court.

25 See http:// www.sigli.ms-aceh.go.id/website/statistik-perkara. Retrieved on May 30, 2014.

26 Interview with Muzakir Muslim, the chairman of the study bureau of Bustanus Salatin Kp. Baro, on June 1, 2012.

27 Case no: 13/Pdt.P/2013/MS.Sgi registered on Wednesday, January 30, 2013. See www.perkara.net. Retrieved on May 30, 2014.

28 Case no: 201/Pdt.G/2012/MS.Sgi registered on Wednesday, August 15, 2012. See www.perkara.net. Retrieved on May 30, 2014.
} 
the Qanun". ${ }^{29}$ The same references are used in the Region of Pidie, Nanggroe Aceh Darussalam.

\section{The Influence of Custom of Pidie Society on Dividing the Wealth of Inheritance}

Each community could not escape from influences customary practices in the division of wealth of inheritance. In this case, the practice of the division of wealth of inheritance in Pidie society can be divided into two aspects, namely customs relating to property and inheritance.

Inheritance refers to all property left behind by the deceased either in the form of objects that belonged to him or rights. ${ }^{30}$ There are several obligation and rights of the treasures that need to be prioritized before they are inherited. The expenses includes for religious and custom practices. For example the expenses of tajhtiz almayyit involving clothes for the bodies and funeral expenses, paying debt, wills, ritual for the souls, part of the wealth earned (areuta seuhareukat), treasures got from parents (areuta peunulang), compensation for missing prayers and reading al-Qur'an in the cemetery of the deceased. The explanation is as follows:

\section{Tajhîz al-Mayyit (handling the deceased)}

It is prevailing in Pidie society that the expenses for tajhtiz almayyit are taken from the treasures left behind by the deceased. The Aceh proverb says "mayet ureng chik tanyoe glah kedroe", which means that "the right of deceased (the expenses for tajhiz al-mayyit) is taken from the estate left behind by the deceased." 31 If the deceased did not leave anything behind, the expenses would be borne by the the deceased family who is able to pay for the expenses or are on loan to be paid off by the heirs from the wealth of inheritance. There is also a

\footnotetext{
29 Sharia Court of Nanggroe Aceh Darussalam, Himpunan Peraturan Perunandgunandgan Tentang Mahkamah Syar'iyah Di Provinsi Nanggroe Aceh Darussalam. Ed. 3, (Banda Aceh: Mahkamah Syar'iyah Provinsi Aceh, 2006), 156.

${ }^{30}$ Nuansa Aulia Editor Team, Kompilasi Hukum Islam, (Bandung: Nuansa Aulia, 2008), 54.

31 Interview with Khalil AMD, an expert of IKADI ( $a^{\prime} i$ Association) North Aceh (2005-2008) on May 31, 2012.
} 
customary practice of financing tajhtz al-mayyit through donation for death given by the local community. ${ }^{32}$

Based on the basic rules set by the Islamic Law Compilation (ILC), expenses for tajhtiz al-mayyit should be taken from the treasures left behind by the deceased before they are allocated to the heirs as wealth of inheritance. This allocation is stated in the book II chapter I general provisions of Article 171 (e), namely:

"Wealth of inheritance is inherited estate and property plus properties earned together after being used for every needs of the testator during illness until death, expenses for handling the corpse (tajhiz), payment of debt, and giving to relatives."

Thus, the Pidie community practices, in this case, are in accordance with the regulation set in ILC and Islamic jurisprudence and it becomes obligatory for the Muslims in the region to apply it. 33

\section{Debt and Will}

Payment of debt of the deceased is done before the wealth of inheritance is distributed. If the debt exceeds the wealth of inheritance, it is an obligation of the heirs to pay it. Likewise, will can be implemented before the division of inheritance, and restricted at maximum of one third of the property left behind by the deceased. ILC provision is in accordance with the practice in which payment of debts and implementation of the will are done before the division of inheritance. This issue is stated in Article 187 paragraph 2 which reads: "The rest of the expenditure referred to above is an inheritance to be distributed to the rightful heir."

The word "expenditure" above means the expenses for tajhiz al-mayyit, payment of debt and the implementation of will of the deceased. Based on the above explanation, the customary practices of Pidie community are in line with sharia law.

\section{Ritual for the Spirits (Arwâh)}

\footnotetext{
32Interview with Izwar Ibrahim, an employee of Sharia Court of Meureudu, on June 6, 2012.

33 Ibn Nujaim al-Hanafi, al-Bahrr al-Raiq Syarh Kunz al-Daqâiq, Vol. 2, (Kaherah: Dar alKitab al-Islami, N.d.), 191-192.
} 
Ritual for the spirits refers to a ritual performed to pray for the spirits of the deceased. 34 The word "arwah (spirits)" is a plural form of "ruh (spirit)" which is singular. The ritual is a custom held by the family of the deceased when inheritance will be distributed to the heirs. In Aceh, the ritual is known as bu leukat kuneng (yellow pulut) becuase it is served with yellow pulut (a traditional food). It is also known as the kenduri nujuh (ritual on the seventh) because it is usually held on the 7th day after the death. It is held on specific dates such as on the $14^{\text {th }}, 30^{\text {th }}, 44^{\text {th }}, 100^{\text {th }}$ or one year after the death and the expenses for these rituals is taken from the property left by the deceased. The rituals are attended by geuchik (village chief), imuem (imam), imuem mukim (chairman of mukim), relatives and orphans. The division of inheritance would be done after the ritual and is attended by the entire family. The process of division of wealth of inheritance is also witnessed by the customs authorities. 35

In Islamic law, the ritual for the spirits is allowed as long as it is in accordance with sharia law, such as the meals for the guests is provided by neighbors or relatives of the deceased who are not the beneficiaries. ${ }^{36}$ This is in line with the Hadith of the Prophet in the case of death of Ja'far stating, "Be devoted to providing food for the family of Ja'far (as) has come to them things distressing (trouble)". ${ }^{37}$

However, it is disapproved in Islamic law if the ritual meals are provided by the family of the deceased and falls into in al-niyâhah, because it has been adding more burdens to their distress, with the exception when the guest coming from distant places and staying overnight. Moreover, the ritual may be haram (forbidden) if customs require families of the deceased to hold the ritual with the cost taken from the wealth of inheritance. ${ }^{38}$ Thus, the practice of ritual for spirits which takes place in Acehnese society is not in accordance with the

\footnotetext{
34 See Kamus Dewan edisi keempat, (Kuala Lumpur: Dewan Bahasa and Pustaka, 2013), 741.

35 Interview with Cut Kaslinda, a Lecture of Ilmu Waris Fakulti Syari'ah UIN ArRaniri on June 10, 2012.

36 See Jalâl al-Dîn al-Suyûthî, al-Hawi li al-Fatawâ, Vol.2, (Syria: Dar al-Fikr, N.d.) 178.

37 See Al-Qazwayni, Sunan Ibn Majah..., Vol.1, 514.

38 Muhammad al-Syatta al-Dimyati al-Bakri, Hasyiyah I'ânah al-Thâlibîn, Vol.2, (Beirut: Dar al-Kutub al-Islamiyyah, 1995), 242-244.
} 
sharia law because its implementation is burdensome for the family members of the deceased.

\section{Fidyah (Ransom) for Shalat}

The word "fidyah" refers to something given as a ransom. Terminologically, fidyah means property or wealth used by someone as ransom for him due to a shortage in worship and in this case is missing the prayer. ${ }^{39}$

The payment of fidyah of prayer applies not only in Pidie, but also in various other areas in Aceh, such as Aceh Besar and Aceh Utara. ${ }^{40}$ Fidyah of prayer is calculated starting from after the age of puberty until the death. The payment is taken from the wealth of inheritance before it is distributed to the heirs. The heirs must pay for the fidyah, which can be rice or the price of the rice, when the inheritance is not enough. It is calculated like fidyah of fast, namely one mudd (566.991 grams of rice) ${ }^{41}$ for every prayer missed.

The issue of payment for fidyah of prayers missed by the deceased is one of the cases disputed by classic scholars. There are three opinions related to this issue:

1) The heirs do not have to perform qadla' prayer or fidyah of a family member who left prayer during his life. This is the opinion of majority of scholars like Malikiyyah, Shafi'iyyah and Hanabilah. The argument is that prayer is "physical worship", there is no authentic hadith found that obliges payments of fidyah for a missed prayer, in contrast to the fasting. ${ }^{42}$ This view is based on the hadith narrated by 'Abd Allah Ibn Umar that the Messenger asked, " is it allowed that someone fast for others, or perform prayers for others? The Prophet, Muhammad answered: someone do not fast for someone else, and do not also perform prayers for others. "43

\footnotetext{
${ }^{39}$ Muhammad 'Ali al-Sabuni, Rawấ'i' al-Bayân Tafsir Ayat al-Ahkâm, Vol. 1, (Damsyiq: Maktabah al-Ghazali, 1980), 189.

${ }^{40}$ Interview with Muhammad Jamaluddin, Khatib of Kp. Baro mosque, on June 2, 2012.

41 Interview with Imran, the chairman of Dayah Darul Amal, Pidie on June 6, 2012.

42 Al-Rafi'i, Fath al-'Azîz, Vol. 6, (Beirut: Dar al-Kutub al-'Ilmiyyah, 1997), 458.

43 See Ibn Malik, Muwaththâ' Malik, Vol. 1, (Beirut: Dar Ihya' al-'Ulum al-'Arabiyyah, 1994), 235.
} 
2) According to some scholars of Syafi'iyyah, heirs do not have to pay fidyah of prayers but perform qadha obligatory prayers which have been missed by the dead. This has been done by al-Subkî who performed qadha prayers for his mother who had passed away. ${ }^{44}$ The view of doing qada' prayer of the deceased is based on analogy (qiyâs) between prayers and fast in terms of qadlấ $\hat{a}^{\prime}$ of the dead. ${ }^{45}$

3) According to some other scholars of Hanafiyyah and Syafi'iyyah, the heirs should pay fidyah for every prayer missed by the deceased by giving out 1 mudd of each prayer and it is unnecessary to perform a qadlấ prayer. According to Imam Abu Hanifah, the fidyah is only paid off if the deceased willed to do so. However, some scholars of Hanafiyyah, state that it is obligatory to pay fidyah although it is not mentioned in the will of the dead. ${ }^{46}$ This view is based on the hadith narrated by Ibn 'Abbas, the Prophet Muhammad said: "Let no one is doing prayers for others and let no one is fasting for others, but for every day missed is given as much food as one mudd of grain." 47

4) According to Majority of scholars, this fidyah is for fasting and not for prayer missed. 48

Based on the discussion above, it can be concluded that the most appropriate opinion is that there should be no fidyah or qadlâ' prayer needs to be done when the deceased has missed a prayer. This is based on an authentic hadith narrated by Malik above. ${ }^{49}$ Thus, paying fidyah of prayers which is practiced by the people of Pidie and several other areas in Aceh is a practice a few Muslim who refers to

44 Muhammad al-Syatta al-Dimyati al-Bakri, Hasyiyah I'ânah..., 33.

45 Al-Bahuti, Kasysyaf al-Qinâ' 'an Matn al-Iqnâ',Vol. 2, (Beirut: 'Alam al-Kutub, 1997) 336.

46 Al-Sarkhasi, al-Mabsûth, Vol.3, (Beirut: Dar al-Ma'rifah, 1989), 90.

47 See Al-Nasâ'î, al-Sunan al-Kubrâ li al-Nasâ'î, Vol.3, (Beirut: Muassasah al-Risalah, 2001), 293

48 `Abd Allah Ibn Yusuf al-Zabla'i, Nasb al-Rayah fi Takhrîj Ahâdîth al-Hidâyah, Vol. 3, (Kaherah: Dar al-Hadith, 1995), 29-31.

49 See work sheet of Ulama consultative Council (MPU) of Lhokseumawe (2007), Bahth al-Masa'il Fidyah Shalat Mazhab Syafi'i, on December 4, 2007. 
the scholarly opinion of Hanafiyya and some scholars of Shafi'iyya based on a hadith narrated by al-Nasa'i.

\section{Reading al-Qur'an on the Grave}

Reading the Koran on the grave of the deceased is practiced starting on the first day of death until the $7^{\text {th }}$ or $44^{\text {th }}$, which is sometimes done for 24 hours. Usually, the wage of reading can cost RM 2,500. This fee is taken out from treasures of the dead, or otherwise, it is on the heirs. ${ }^{50}$ Although it is not an obligation, it is mostly practiced in the area of Pidie with the belief and purpose to ease the torment of the dead.

With regard to this practice, scholars have different views related to whether the prayers benefit the dead or not. According to the view of ahl sunnah wa al-jamâ'ah, except Malik and Shafi'i, reward of reciting the Quran benifits the dead. It is based on a hadith narrated by Ma'qil Ibn Yasar saying that the Prophet said: "Recite Surah Yasin for your brother who has died." 51 Otherwise, the Prophet certainly would not tell such.

However, in the view of Shafi'i, recitation of the Qur'an for the dead will not give any benefit to him. The argument is based on the word of Allah which can be understood that there is no (reward or punishment) for a person except on what he has strived for. ${ }^{52} \mathrm{Also}$, on a hadith of the Prophet which states that when a human being dies, all of his deeds except for three types: an ongoing charity, beneficial knowledge, and a righteous child who prays for him. 53 This shows that the recitation of the Koran would not benefit the deceased except from a pious child who prayes for his parents who had died. 54

Based on both opinions above, it can be concluded that a reward for a person who has died is determined solely by good deeds done during his life in the forms of perpetual charity, beneficial knowledge, and a rightful child who prays for his parents.

\footnotetext{
50 Interview with Khalil AMD, Ibid.

51 See Al-Sajastani al-Azdi, Sunan Abi Dawûu, (Beirut: Al-Maktabah al-'Asriyyah, N.d.), 3121. 
Meanwhile, a Muslim prayer for the dead person is an effort of the living so that the dead gets Mercy of prayers offered.

However, reading al-Quran for the dead in the form that is practiced by Pidie community involving time and date, and a certain fee can be classified as a provision that is not in accordance with sharia law. This is because the practice place financial burdens on the family members of the dead. It also shows the involvement of wage for rewards that should be earned during a person's life.

\section{Areuta Peunulang}

Areuta peunulang refers to gifts given by parents the girls who had been married, which is usually a home and the yard. Usually, the gift is verbally stated in order that the daughter is not neglected if she is divorced later. Similarly, it is regarded as remuneration for custody of his parents during illness. In Aceh, this right is recognized as a right of hak peutimang ureung chik which means the right of taking a care the parents. ${ }^{55}$

According to customary practice, the property is given by parents when they are still alive. However, people have different understanding of it; first, the gift is considered as a grant from parents, so that it does not reduce the shares of inheritance received by daughters after their parents have died. ${ }^{56}$ However, this provision requires permission of other heirs if the girls are given more shares. Had the parents given their all properties to a daughter, areuta peunulang should have been only $1 / 3$, while $2 / 3$ of the property would have been inheritance which is the right of the heirs, including the girl. 57

The second view considers areuta peunulang as a part of inheritance although it has been given before the parents died. 58 Thus, the daughter's right to inheritance will be rejected by the areuta peunulang in the division of inheritance.

\footnotetext{
55 Interview with Muhammad Sulaiman, loc.cit.

56 Interview with Cut kaslinda, loc.cit.

57 Interview with Muhammad Jamaluddin, loc.cit.

58 Interview with Zainuddin Muhammad Thaib, a free proselytzer, on June 6, 2012.
} 
In Islamic law, the gifts given while one is alive is considered as hibah (a grant) instead of an inheritance. ${ }^{59} \mathrm{~A}$ grant is a transfer of a property ownership when a person is still alive, while the inheritance is a transfer of ownership of a property when someone has died. A grant should not be withdrawn except that from parents to children as the Prophet mentions it like "a man who swallows back his vomit".60It is required to be fair when giving a grant to children to avoid disputes. Therefore, it is recommended to give a grant under the permission of other heirs when not all heirs get it. ${ }^{61}$ This is based on the hadith of the Prophet narrated by Nu'man Ibn Basyir "..... and fear Allah and be fair to your children." 62 From the explanation above, it can be concluded that the custom of giving areuta peunulang practiced by Pidie community is in accordance with sharia law.

\section{A Joint Property (Areuta Seuhareukat)}

In Aceh, Areuta seuhareukat is recognized as wealth earned together by a husband and wife when they are in a marital bond. ${ }^{63}$ Experts on customary law such as Hilman Hadikusuma defines " Areuta seuhareukat " to refers to all income of husband and wife during the marriage bond, apart from a brought and given property, either the wife works or not. If they get divorced or either of them dies, the property is devided equally between the husband and wife. ${ }^{64}$

In the case of divorce either the couple alive or die, the joint property would be divided to each partner according to the custom through a deliberation. Usually, the division of property takes two forms, namely: 65

I. Equal distribution which is done if the husband and wife work with the same level of job. Mean while, the majority of people do not require the wife to work in which, in this case, the wife

\footnotetext{
59 See Mansur al-Bahuti, Kasyaf al-Qinâ' 'an Matn al-Iqnâ', Ed. 1, Vol. 3, (Beirut: 'alam al-Kutub, 1997), 496.

60 See Al-Bukhari, Shahih al-Bukhari, Vol. 1, (Beirut: Dar Ibn Kathir, 1993), 924.

61 'Abd al-Rahman al-Maqdisi, Al-'Uddah Syarh al-'Umdah, (Beirut: Maktabah al'Asriyyah, N.d.), 280.

62 See Muslim, op. cit., Vol. 3, 1243.

63 See Article 35 (1) Act No. 1 /1974 about marriage.

${ }^{64}$ Hilman Hadikusuma, Hukum Waris Adat, (Bandung: Citra Aditya Bakti, 2003), 60.

65 Interview with Muhammad Jamaluddin, loc.cit.
} 
would still get half of areuta seuhareukat although she is a housewife.

II. The division of $1 / 3$ for the wife and $2 / 3$ for the husband when it is only the husband who works while the wife is a housewife, or both the husband and the wife work but the level of the wife's job is lower than the husband's.

In the perspective of Islamic law, the "joint property" is an issue of tradition and applies in the region of Malay community. It is not recognized in previous studies of figh (Islamic jurisprudence) or not addressed specifically by the scholars of the past. Thus, the local Muslim jurists like Amir Syarifuddin 66 and Ma'ruf Amin ${ }^{67}$ make an analogy that the law of "joint property" is like the law of syirkah or syarikah (partnership) in a family. Meanwhile, Ismail Muhammad Syah $^{68}$ considers it as syirkah mufâwadlah and abdan on the basis of unlimited partnership. Indeed, any properties earned during the marriage where both the husband and wife work in their marriage time would be joint properties. ${ }^{6}$

\section{Conclusion}

Act of Islamic inheritance constitutes provision of Allah through definite passages, namely verses 11, 12 and 176 of surah alNisa'. However, there are some additional laws that are not explained in the verses above but has been described in the hadith of the Prophet Muhammad. It is the space for ijtihâd and customs to addresses other issues not clearly addressed by the Quran and hadith as long as they are not against sharia laws. It is clear that Islam admits customary practices as long as it is in accordance with the spirit of sharia. In fact, the declaration of inheritance as Islamic law occurs in the way of tadarruj (gradually) in which, initially, sharia admits some customary practices. This shows that Islam accepts custom as

\footnotetext{
66 Amir Syarifuddin, Hukum Perkawinan Islam di Indonesia, Antara Fikih Munakahat and Unandg-Unandg Perkawinan, Ed. 1, (Jakarta: Prenada Media, 2006), 175-176.

67 The chairman of Fatwa commission of Indonesian Ulema Council. See Anggun Magazine, No. 22, Vol. 2, March 2007.

68 Ismail Muhammad Syah, Pencaharian Bersama Suami Istri, (Jakarta: PT. Bulan Bintang, 1965), 63.

${ }^{69} \mathrm{Ibid}, 64$.
} 
justification for defining regulation as long it is not against the sharia laws.

It is found in this study that the effect of the customary practices on the division of inheritance in Pidie Community can be divided into allowed customs (sahîh) and forbidden customs (fâsid). The example of allowed customs is the division of joint property and grants for daughters. As for the example of forbidden customs is a wage of the Quran recitation on the grave of the dead, ritual for the spirits, and paying fidyah for the prayers missed by the deceased during his lifetime. Thus, Pidie community should abandon these deeds which are against the view of ahl sunnah wal jamâ'ah.

\section{References}

'Âbidin, Ibn, Rad al-Muhtar 'ala al-Dur al-Mukhtar Syarh Tanwir alAbsar, Riyad: Dar 'Alim al-Kutub, 2003

'Arabiyyah, Majma' al-Lughah al-, Al-Mu'jam al-Wasith, ed. 4, Kaherah: Maktabah al-Syuruq al-Dawliyyah, 2004

'Âsyûr, Musthafa, 'Ilm al-Mirâth, Kaherah: Maktabah al-Qur'an. n.d.

Azdî, Sulayman Ibn al-Asy'at al-Sajastanî al-, Sunan Abi Dawûd. Beirut: Al-Maktabah al-'Asriyyah, N.d.

Bahuti, Mansur Ibn Yunus Ibn Idris al-, Kasysyâf al-Qinâ' 'an Matn alIqnâ', Ed. 1, Beirut: 'alam al-Kutub, 1997

Bakri, Muhammad al-Syatta al-Dimyati al-, Hasyiyah I'ânah al-Thâlibîn. ed. 1. Beirut: Dar al-Kutub al-Islamiyyah, 1995

Bayhaqî, Al-, al-Sunan al-Kubrâ.Beirut: Dar: al-Ma'rifah, N.d.

Bayjuri, Ibrahim al-, Hasyiyyah al-Bayjurî 'ala Syarh Ibn al-Qâsim 'ala Syarh Matn Abi Syujấ, ed. 2, Beirut: Dar al-Kutub alIslamiyyah, 1999

Faradi, Ibrahim Ibn Abdullah Ibn Ibrahim al- (), al-'Adhb al-Faid Syarh 'Umdah al-Farid, Beirut: Dar al-Kutub al-'Ilmiyyah. 1999

Hadikusuma, Hilman, Hukum Waris Adat, Bandung: Citra Aditya Bakti, 2003

Hanafi, Zainuddin Ibn Nujaim al-, Al-Bahr al-Râiq Syarh Kunz alDaqâiq, Kaherah: Dar al-Kitab al-Islami, N.d.

Ja'fi, Muhammad Ibn Isma'il al-Bukhari al-, Shahîh al-Bukhârî, Beirut: Dar Ibn Kathir, 1993

Jalâl al-Dîn al-Suyûthî, al-Hawi li al-Fatawâ,, Syria: Dar al-Fikr, N.d. 
Jundi, Muhammad al-Syahat al-, al-Mirâth fi al-Syari'ah al-Islâmiyyah. Kaherah: Dar al-Fikr al-'Arabi, N.d.

Kamus Dewan edisi keempat, Kuala Lumpur: Dewan Bahasa dan Pustaka, 2013

Work sheet of Ulema Consultative Council (MPU) Lhokseumawe, Bahth al-Masâ'il Fidyah Shalât Mazhab Syâfi'î, Desember 4, 2007.

Sharia Court of the province of Nanggroe Aceh Darussalam, Himpunan Peraturan Perundang-undangan Tentang Mahkamah Syar'iyah Di Provinsi Nanggroe Aceh Darussalam, Ed. 3, Banda Aceh: Mahkamah Syar'iyah Provinsi Aceh, 2006

Malik, Malik Ibn Anas Ibn, Muwattâ', Beirut: Dar Ihya' al-'Ulum al'Arabiyyah, 1994

Maqdisî, 'Abd al-Rahman Ibn Ibrahim al-, Al-'Uddah Syarh al'Umdah.Beirut: Maktabah al-'Asriyyah, N.d

Namlah, Abdul Karim Ibn 'Ali Ibn Muhammad al-, al-Jâmi' li Masấil Ushûl al-Fiqh. Riyad: Maktabah al-Rusyd, 1999

Nasa'i, Ahmad Ibn Syu'ayb Ibn 'Ali Ibn Sinan Ibn Bajr al-, al-Sunan alKubrâ li al-Nasâ'î. Beirut: Muassasah al-Risalah, 2001

Nawâwî, Yahya Ibn Syarf Abu Zakariyya al-, Syarh al-Nawâwî̀ 'ala Muslim. Kaherah: Dar al-Salam, 1996

Naysaburî, Muslim al-Hujaj al-Qusyayri al-, Sahîh Muslim, Mesir: Dar Ihya' al-Kutub al-'Arabiyyah, N.d

Qazwayni, Muhammad Ibn Yazid al-, Sunan Ibn Majah, Beirut: alMaktabah al-'Ilmiyyah, N.d

Rafi'i, Abdul Karim Ibn Muhammad al-, Fath al-'Azîz, Beirut: Dar alKutub al-'Ilmiyyah, 1997

Sabuni, Muhammad 'Ali al-, Rawâ'i' al-Bayân Tafsî̀ Ayat al-Ahkâm, Ed. 3. Damsyiq: Maktabah al-Ghazali, 1980

Dar al-Sabuni.

Sarkhasi, Muhammad Ibn Ahmad Ibn Abi Sahl al-, Al-Mabsût, Beirut: Dar al-Ma' rifah, 1989

Syah, Ismail Muhammad, Pencaharian Bersama Suami Istri, Jakarta: PT. Bulan Bintang, 1965

Syarifuddin, Amir, Hukum Perkawinan Islam di Indonesia, Antara Fikih Munakahat dan Undang-Undang Perkawinan, Ed. 1, Jakarta: Prenada Media, 2006 
Nuansa Aulia Editor Team, Kompilasi Hukum Islam, Bandung: Nuansa Aulia, 2008

Turmuzi, Al-, Sunan al-Turmuzî. Beirut: Dar al-Kutubal-'Ilmiyyah, N.d.

Wasil, Nasr Farid Muhammad, Fiqh al-Mawârith wa al-Washiyyah fi alSyarî'ah al-Islâmiyyah. Mesir: al-Maktabah al-Taufiqiyyah, 1995

Yasu'i, Al-Ab Luwis Ma'luf al-, al-Munjid fi al-Lughah, Beirut: alKathulikiyyah, N.d

Zabla'i, Abdullah Ibn Yusuf al-, Nasb al-Rayah fi Takhrîj Ahâdith alHidâyah, ed. 1. Kaherah: Dar al-Hadith, 1995

Zarqa, Mustafa Ahmad al-, Al-Madkhal al-Fiqhî al-'Âm. ed. 2, Damsyiq: Dar al-Qalam, 2004

Zaydan, 'Abdul Karim, Al-Wajîz fi Syarh al-Qawấ'id al-Fiqhiyyah fi alSyarî'ah al-Islâmiyyah, Ed. 1, Beirut: Muassasah al-Risalah., 2001

\section{List of Statutes}

Act No. 1/1974 about marriang, Articlel 35, verse 1.

Act No. 7/1989 Article 49 on Religious Court.

Regional Regulation No. 7/2000 concerning the life of indigenous customs

Qanun No. 5/2003 about Gampong Government

\section{Interviews}

Cut Kaslinda, a lecturer of Ilmu waris at the faculty of sharia, Universiti Islam Negeri Ar-Raniri Banda Aceh.

Imran, Mudir Dayah Darul Amal, Pidie.

Izwar Ibrahim, an employee at Sharia Court of Meureudu, Pidie.

Khalil AMD, an expert of IKADI (Da'i Association) North Aceh (20052008).

Muhammad Jamaluddin, Imam/Khatib of Kp. Baro Mosque, Pidie.

Muzakir Muslim, a Chairman of study bureau of Bustanus Salatin Kp. Baro, Pidie.

Zainuddin Muhammad Thaib, free Proselytizer, lives in Pidie. 